\title{
Rubricyte Count
}

National Cancer Institute

\section{Source}

National Cancer Institute. Rubricyte Count. NCI Thesaurus. Code C128978.

The determination of the amount of rubricytes present in a sample. 